\title{
Profil Kemampuan Afektif Siswa SMP pada Mata Pelajaran IPA Ditinjau dari Gaya Belajar
}

\author{
Aswar Anas a, 1*, Septi Budi Sartika ${ }^{\text {b, } 2}$ \\ a,b Program Studi Pendidikan IPA, Universitas Muhammadiyah Sidoarjo, Jalan Mojopahit 666 B Sidoarjo 61215 \\ 1azwaranasz.aa@gmail.com* \\ *korespondensi penulis
}

\begin{abstract}
ABSTRAK
Penelitian bertujuan untuk mendeskripsikan kemampuan afektif siswa SMP pada mata pelajaran IPA yang ditinjau dari gaya belajar. Metode penelitian menggunakan penelitian kualitatif deskriptif dengan triangulasi sumber. Sumber yang diteliti meliputi 3 subjek yaitu siswa dengan gaya belajar berbeda, 1 guru IPA, dan 3 teman sebangku masing-masing subjek di salah satu SMP berbasis pondok pesantren di Sidoarjo Jawa Timur. Angket kemampuan afektif menjadi instrumen untuk mengambil data secara online melalui google form. Hasil data dari angket akan dianalisis menggunakan triangulasi sumber, hasil angket dari masing-masing subjek akan dianalisis dengan data dari subjek lain. Hasil penelitian menunjukkan bahwa profil kemampuan afektif pada pembelajaran IPA di SMP Al Fallah Sidoarjo sebagai berikut: 1) subjek dengan gaya belajar visual mencapai semua indikator kemampuan afektif yaitu menerima, merespon, menghargai, mengorganisasi, dan karakterisasi berdasarkan nilai-nilai, 2) subjek dengan gaya belajar auditori mencapai 2 indikator kemampuan afektif yaitu menerima dan merespon, dan 3) subjek dengan gaya belajar kinestetik mencapai 1 indikator kemampuan afektif yaitu merespon. Penelitian yang telah dilakukan hanya sampai mengungkap fenomena kemampuan afektif pada gaya belajar yang berbeda dengan instrumen angket, penelitian selanjutnya diharapkan mampu menganalisis secara mendalam kemampuan afektif siswa berdasarkan peninjauan yang lainnya dengan menggunakan instrumen dan triangulasi yang lainnya.
\end{abstract}

Kata kunci : gaya belajar, kemampuan afektif, IPA, siswa SMP

\begin{abstract}
The research aims to describe the affective abilities of secondary school students in natural science subjects that are reviewed from the learning style. The research method uses descriptive qualitative research with source triangulation. The sources studied included 3 subjects, namely students with different learning styles, 1 science teacher, and 3 classmates of each subject in one of the boarding school-based secondary schools in Sidoarjo, East Java. The affective ability questionnaire becomes an instrument for retrieving data online via google form. The results of the data from the questionnaire will be analyzed using triangulation of sources, the results of data from student subjects will be analyzed with data from other subjects. The results showed that the affective ability profile in natural science learning at SMP Al Fallah Sidoarjo as follows: 1) subjects with visual learning styles achieved all indicators of affective ability i.e. receiving, responding, appreciating, organizing, and characterization based on values, 2) subjects with auditory learning styles achieved 2 indicators of affective ability i.e. receiving and responding, and 3) subjects with kinesthetic learning styles achieved 1 indicators of affective ability i.e responding. Research that has been done only to uncover the phenomenon of affective ability in different learning styles with questionnaire instruments, further research is expected to be able to analyze in depth the affective abilities of students based on other reviews using other instruments and triangulations.
\end{abstract}

Keyword: affective ability, learning styles, natural science, secondary school students

\section{PENDAHULUAN}

Di tengah gencarnya upaya pemerintah dalam meningkatkan keefektifan pendidikan, ada satu hal yang harus diperhatikan, yaitu keseimbangan antara aspek afektif, kognitif, dan psikomotorik (Nyumirah, 2013). Keseimbangan tiga aspek ini harus diperhatikan dengan baik dan seksama untuk mencapai pendidikan yang diinginkan dengan baik. Saat ini pemerintah menghadirkan sistem yang dianggap paling tepat untuk diaplikasikan pada pendidikan di Indonesia. Dengan asumsi adanya penekanan pada aspek afektif diharapkan bisa membangun karakter pemuda bangsa ini. Sebuah bangsa memerlukan perubahan positif yang dilakukan oleh pemuda, dan proses itu sangat ditentukan oleh sistem pendidikan (Salim, 2018). Setiap orang meyakini bahwa pendidikan adalah jalan untuk menuju 
masa depan yang lebih baik. Melalui pendidikan, para orang tua berharap kelak anak-anak mereka akan menjadi bibit penerus bangsa yang bertalenta (Hasibuan, 2018).

Pemerintah Republik Indonesia melalui Menteri Pendidikan dan Kebudayaan membuat sebuah sistem baru berupa kurikulum yang dapat menciptakan generasi bangsa menjadi generasi yang berkarakter dan beretika (Sulistiyowati, 2014). Tentu langkah ini adalah langkah yang baik untuk mewujudkan cita-cita bangsa seperti yang tertuang dalam Pembukaan UUD 1945. Untuk menciptakan bangsa yang berkarakter dan beretika tentu tidak cukup siswa tersebut pandai, perilaku, adab, etika juga kemampuan menalar yang tinggi dibutuhkan. Ranah kemampuan afektif diperlukan di sistem pendidikan sekarang dan yang akan datang. Dengan karakter dan etika yang terbentuk melalui penilaian kemampuan ranah afektif akan mempermudah terbentuknya kepribadian yang baik pada setiap siswa. Ini juga menjadi sebuah perubahan besar, dimana guru tidak lagi mementingkan kepandaian siswa dengan menilai kemampuan kognitif dalam mengerjakan soal dan kemampuan psikomotor dalam hal praktik. Namun guru akan menilai kecerdasan siswa tersebut dalam kemampuan afektif yaitu melalui sikapnya.

Sikap atau etika siswa saat ini sudah melampaui batas normal. Beberapa kasus penganiayaan guru oleh siswa bahkan orang tua siswa sering terjadi (Mulyasa, 2014). Tentu ini menjadi perhatian penting bagi pemerintah di dunia pendidikan. Benar saja jika tidak semua siswa pandai bisa berperilaku baik, namun siswa yang berperilaku baik dapat menjadi siswa yang pandai. Untuk itu keseimbangan tiga kemampuan ini harus diperhatikan dengan benar. Siswa harus paham bahwa yang menjadi tolak ukur atau indikator nilai bukan hanya kecerdasan otak, namun sikap dalam setiap kegiatan belajar mengajar.

Kegiatan belajar mengajar tentu memiliki berpengaruh besar dalam membentuk karakter siswa. Untuk itu penekanan pengajaran kemampuan afektif dan penilaiannya harus dilakukan. Dengan siswa yang pandai dan juga memiliki prilaku yang baik, dapat menghargai guru, teman, bekerja sama dan saling membantu tentu akan lebih mempermudah kegiatan belajar mengajar. Dalam kegiatan belajar mengajar tentu setiap kemampuan mempunyai indikator sendiri untuk standart penilaian. Indikator tersebut dapat mejadi tolak ukur guru untuk melihat apakah siswa tersebut telah berhasil mencapai kemampuan pada setiap ranah atau belum. Ranah afektif mempunyai indikator yang mendeskripsikan ranah afektif itu sendiri.

Ranah afektif itu sendiri adalah kemampuan dari hasil belajar yang tampak pada siswa dalam berbagai macam keadaan atau tingkah laku mereka (Basrowi, 2012), seperti memperhatikan, merespon, menghargai, mengorganisasi diri dan lingkungan, serta karakterisasi nilai mereka. Ranah afektif mempunyai beberapa macam tipe menurut Bloom, ranah afektif sebagai nilai hasil belajar kategori tersebut yang dimulai dari tingkat sederhana/ rendah sampai ke tingkat yang lebih rinci/ kompleks, yaitu: receiving/ menerima, yaitu semacam kepekaan/ kesadaran dalam menerima rangsangan/ stimulasi, responding/ merespon, yaitu reaksi yang diberikan oleh seseorang terhadap stimulasi yang berasal dari luar. Valuing/ menghargai adalah indikator yang berkaitan dengan nilai percayaan terhadap gejala dan stimulus (Khoeron, 2014) selain itu Arifin (dalam Rosa, 2015) mengatakan dalam, penilaian afektif ada 2 hal yang harus dinilai. Hal pertama, kompetensi kemampuan afektif dalam kegiatan belajar mengajar meliputi aspek pemberian stimulus, merespon, menghargai, menilai dan internalisasi. Hal kedua adalah sikap dan minat siswa kepada mata pelajaran yang diberikan oleh guru juga pada proses pembelajaran. Dalam proses pembelajaran juga terdapat 4 tipe karakter yang penting yang perlu untuk diperhatikan, yaitu sikap, karakter diri, minat, dan nilai. Semua komponen itu sangat diperlukan untuk menunjang kegiatan belajar mengajar.

Kegiatan belajar mengajar IPA di SMP YPP Al-Fattah telah diamati diperoleh bahwa sistem sekolah berbasis pondok pesantren yang mengharuskan siswa tinggal di sana, guru dapat mengetahui dan mengontrol setiap kegiatan siswa termasuk juga kemampuan afektif siswa. Terlebih sikap lembut guru saat menyampaikan materi kepada siswanya menjadi nilai positif untuk keberlangsungan kegiatan 
belajar mengajar. Hal itu membuat siswa dapat menunjukkan kemampuan afektifnya meskipun beberap indikator belum tercapai.

Tercapainya indikator afektif dapat mempengaruhi proses belajar mengajar. Hasil kegiatan belajar sendiri dapat dilihat melalui tahap penilaian, terdapat beberapa faktor internal yang mempengaruhi seperti, tingkat kecerdasan, bakat, sikap, minat, motivasi, tanggung jawab, dan gaya belajar (Sukanti, 2011). Dengan adanya faktor seperti sikap, minat, tanggung jawab secara tidak langsung mewakili pentingnya kemampuan afektif siswa. Gaya belajar juga menjadi faktor yang perlu diperhatikan, karena gaya belajar sendiri adalah usaha yang dilakukan individu untuk menerima materi dengan baik dan mencapai tujuan dalam belajar (Anggraini, 2012). Gaya belajar memiliki tiga tipe pokok yaitu, gaya belajar visual, gaya belajar auditori, dan juga gaya belajar kinestetik (Arini, 2017). Setiap gaya belajar memiliki karakteristik mereka tersendiri. Karakteristik setiap gaya belajar juga menentukan bagaimana cara terbaik siswa dalam menerima materi juga mengolah materi tersebut. Dengan mengetahui karakteristik setiap gaya belajar, guru juga dapat mengerti setiap kemampuan siswanya terutama kemapuan afektif, karena setiap gaya belajar memiliki sifat yang nampak pada saat proses kegiatan belajar mengajar (Hartati, 2015).

Proses belajar mengajar menjadi peristiwa terpenting siswa untuk mendapatkan ilmu secara akademis. Dengan demikian kegiatan belajar mengajar haruslah berjalan dengan baik. Keberhasilan dari kegiatan belajar mengajar dapat disebabkan oleh beberapa hal termasuk sikap dan gaya belajar siswa (Anggraini, 2012), sikap dan gaya belajar siswa memang berpengaruh besar pada saat kegiatan belajar mengajar termasuk pada prestasi atau nilai akhir (Aliffah, 2013). Sikap yang ditunjukkan siswa saat menerima materi sangatlah berpengaruh dalam output mereka setelah menerima materi tersebut. Sikap suka dan tidak suka saat guru memberikan materi kepada siswa adalah indikator utama yang dapat membuat nilai siswa baik atau tidak. Hal ini dikarenakan kondisi saat siswa menerima materi dengan baik dan saat siswa menerima materi dengan tidak baik akan sanagat berbeda. Gaya belajar siswa juga menjadi salah satu faktor yang mengakibatkan siswa dapat menerima dengan baik atau tidak materi yang disampaikan oleh guru (Taiyep dan Mukhlisa, 2015). Ketika materi disampaikan dengan cara yang membuat salah satu gaya belajar tidak nyaman atau tidak dapat mencerna materi tersebut dengan cara mereka, otomatis siswa tersebut akan merasa tidak suka dengan materi yang disampaikan oleh guru. Proses ini umumnya terjadi di awal sampai akhir proses belajar mengajar.

\section{METODE}

Penelitian ini menggunakan metode kualitatif deskriptif (Gunawan, 2013) yaitu penelitian tanpa memberi perlakuan atau manipulasi pada variabel dan sumber yang diteliti, penelitian ini lebih menekankan makna pada hasil (Bire, 2014). Pada penelitian ini triangulasi sumber dipilih untuk mencari kredibilitas data hasil penelitian. Sumber penelitian ada 3 yaitu 3 siswa dengan gaya belajar berbeda (gaya belajar visual, auditori, dan kinestetik), 1 orang guru mata pelajaran IPA, dan 3 teman sebangku siswa dengan gaya belajar yang berbeda. Instrumen yang digunakan adalah angket, angket diukur dengan menggunakan skala Guttman yaitu ya $(\sqrt{ })$ dan tidak $(-)$, yang selanjutnya dibagikan kepada setiap sumber. Angket tersebut berisikan 25 pernyataan dari 5 indikator kemampuan afektif yaitu menerima, merespon, menghargai, mengorganisasi, dan karakterisasi berdasarkan nilai (Adaptasi dari Prastawa, 2013). Setiap indikator menjabarkan karakteristik mata pelajaran IPA di SMP. Angket ini telah divalidasi oleh validator dan mendapat nilai yang baik dan layak untuk dijadikan instrumen untuk mengambil data tentang profil kemampuan afektif siswa ditinjau dari gaya belajar. Penelitian kualitatif tidak menggunakan statistik, tetapi melalui pengumpulan data, analisis, kemudian diintepretasikan (Anggito \& Setiawan, 2018). Berikut angket yang digunakan untuk mengetahui kemampuan afektif siswa dengan gaya belajar yang berbeda: 
Tabel 1. Angket Kemampuan Afektif

\begin{tabular}{|c|c|c|}
\hline No & Indikator & Aspek \\
\hline \multirow[t]{5}{*}{1} & \multirow[t]{5}{*}{ Menerima } & $\begin{array}{l}\text { 1. Menanyakan fenomena alam untuk menarik perhatian pada materi } \\
\text { IPA yang akan disampaikan. }\end{array}$ \\
\hline & & Menunjukkan perhatian kepada guru saat menyampaikan materi IPA. \\
\hline & & $\begin{array}{l}\text { 3. Mengikuti petunjuk guru dalam menyelesaikan tugas atau praktikum } \\
\text { IPA. }\end{array}$ \\
\hline & & 4. $\quad$ Menjawab evaluasi materi IPA. \\
\hline & & Mengikuti kesimpulan materi IPA yang disampaikan. \\
\hline \multirow[t]{5}{*}{2} & \multirow[t]{5}{*}{ Merespon } & Mendiskusikan fenomena alam pada materi IPA yang disampaikan. \\
\hline & & $\begin{array}{l}\text { 7. Berperan aktif dalam menyampaikan pendapat ketika kesulitan dalam } \\
\text { materi IPA. }\end{array}$ \\
\hline & & 8. $\quad$ Mendiskusikan pendapat teman yang menyimpang dari konsep IPA. \\
\hline & & 9. Melaksanakan tugas/ kegiatan evaluasi materi IPA. \\
\hline & & $\begin{array}{l}\text { 10. Menyatakan setuju terhadap kesimpulan materi IPA yang } \\
\text { disampaikan. }\end{array}$ \\
\hline \multirow[t]{5}{*}{3} & \multirow[t]{5}{*}{ Menghargai } & $\begin{array}{l}\text { 11. Mengikuti penyampaian fenomena alam materi IPA yang diberikan } \\
\text { guru dengan seksama. }\end{array}$ \\
\hline & & $\begin{array}{l}\text { 12. Menyampaikan pendapat dalam menangkap materi IPA yang guru } \\
\text { sampaikan. }\end{array}$ \\
\hline & & $\begin{array}{l}\text { 13. Melaksanakan kegiatan penyelesaikan tugas atau praktikum IPA tepat } \\
\text { waktu. }\end{array}$ \\
\hline & & 14. Menyatakan pendapat untuk evaluasi materi IPA. \\
\hline & & 15. Menerima hasil kesimpulan yang guru berikan. \\
\hline \multirow[t]{5}{*}{4} & \multirow[t]{5}{*}{ Mengorganisasi } & $\begin{array}{l}\text { 16. Menghubungkan pengetahuan awal mengenai materi IPA dengan } \\
\text { fenomena alam yang disampaikan guru. }\end{array}$ \\
\hline & & 17. Menyusun catatan/ peta konsep materi IPA yang guru berikan. \\
\hline & & $\begin{array}{l}\text { 18. Mengkoordinir diskusi dengan teman untuk mempermudah } \\
\text { mengerjakan tugas yang guru berikan. }\end{array}$ \\
\hline & & 19. Menyususn tugas evaluasi yang guru berikan sesuai dengan perintah. \\
\hline & & $\begin{array}{l}\text { 20. Menyempurnakan materi IPA yang guru sampaikan untuk menarik } \\
\text { kesimpulan bersama. }\end{array}$ \\
\hline \multirow[t]{5}{*}{5} & \multirow{5}{*}{$\begin{array}{l}\text { Karakterisasi } \\
\text { berdasarkan } \\
\text { Nilai }\end{array}$} & 21. Membuktikan fenomena alam dari guru untuk memahami materi IPA. \\
\hline & & $\begin{array}{l}\text { 22. Memperhatikan materi IPA terlebih dahulu secara mandiri agar bisa } \\
\text { menerima materi yang akan disampaikan guru. }\end{array}$ \\
\hline & & $\begin{array}{l}\text { 23. Membuktikan hipotesis melalui praktikum IPA sesuai prosedur yang } \\
\text { telah ditentukan. }\end{array}$ \\
\hline & & 24. Bertindak dalam penyelesaikan tugas/ evaluasi IPA tepat waktu. \\
\hline & & $\begin{array}{l}\text { 25. Melibatkan diri dalam penyampaian pendapat saat menarik } \\
\text { kesimpulan materi IPA yang dipelajari. }\end{array}$ \\
\hline
\end{tabular}

Angket ini diberikan kepada 3 siswa dengan gaya belajar yang berbeda, 1 guru IPA dengan mengisi kemampuan afektif ketuga siswa dengan gaya belajar yang berbeda, dan 3 teman sebangku siswa yang bersangkutan secara bersamaan melalui google form dengan membagikan link. Hasil angket akan disajikan ke dalam diagram batang, sehingga akan tampak ketercapaian masing-masing indikator. 


\section{HASIL DAN PEMBAHASAN}

Hasil penelitian berupa data hasil angket tentang profil kemampuan afektif berdasarkan gaya belajar siswa dari 3 sumber yaitu 3 siswa dengan gaya belajar yang berbeda, 1 guru IPA, dan 3 teman sebangku masing-masing siswa yang bersangkutan telah dikatakan kredibel, adapun data hasil angket dapat diabstraksikan sebagai berikut:

\section{Profil Kemampuan Afektif Siswa dengan Gaya Belajar Visual}

Berikut dipaparkan hasil angket kemampuan afektif siswa dengan gaya belajar visual dari 3 sumber, yaitu 1 siswa dengan gaya belajar visual, 1 guru IPA, dan 1 teman sebangku siswa dengan gaya belajar visual:

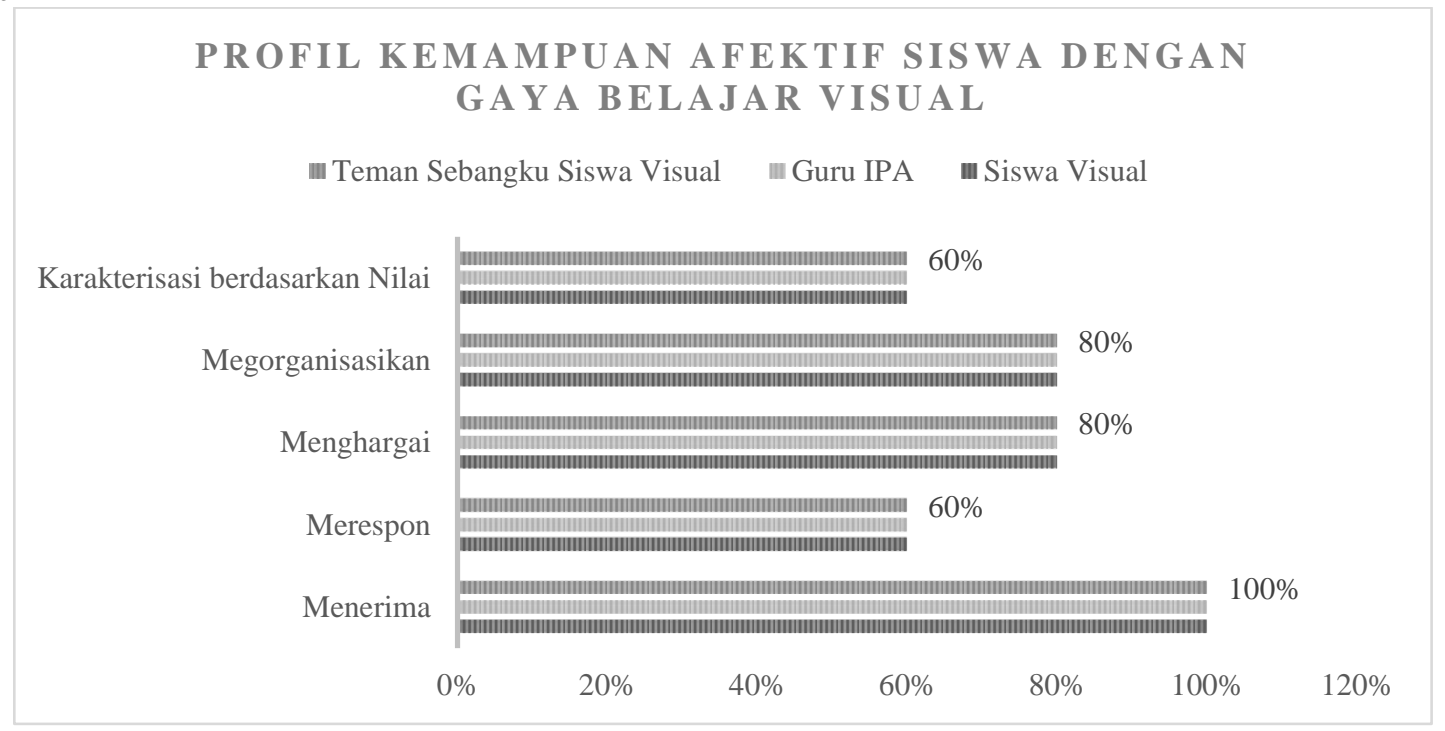

Gambar 1. Diagram Profil Kemampuan Afektif Siswa dengan Gaya Belajar Visual

Profil kemampuan afektif siswa dengan gaya belajar visual yaitu dari 5 indikator hanya 1 indikator yang muncul semua yaitu indikator menerima, sedangkan 4 indikator lainnya tidak muncul semuanya, yang meliputi merespon, menghargai, mengorganisasikan, dan karakterisasi berdasarkan nilai. Namun demikian, proporsi aspek yang muncul dari masing-masing indikator sudah terwakili, artinya ke 5 indikator kemampuan afektif dapat teramati. Keberhasilan kegiatan belajar mengajar IPA dapat dilihat melalui tahap penilaian, terdapat beberapa faktor internal yang mempengaruhi seperti, tingkat kecerdasan, bakat, sikap, minat motivasi, tanggung jawab, dan gaya belajar (Anggraini, 2012). Kelima indikator kemampuan afektif siswa dengan gaya belajar visual sangat baik, yang dibuktikan dengan munculnya seluruh aspek pada indikator tersebut, seperti yang kita ketahui kemampuan afektif sangat berperan penting pada kegiatan belajar mengajar termasuk pada hasilnya (Rijal, 2015). Hal ini sejalan dengan penelitian Amin (2016), bahwa subjek visual memperoleh hasil paling baik. Siswa dengan gaya belajar visual menjadi siswa dengan kemampuan afektif paling baik, ini dikarenakan siswa mampu memunculkan sebagian besar indikator kemampuan afektif. Data ini juga didukung dari informasi guru IPA bahwa siswa dengan gaya belajar visual mempunyai karakter individu yang dikenal baik dan ramah, serta selama ini dikenal dengan siswa yang pandai di berbagai mata pelajaran termasuk mata pelajaran IPA.

\section{Profil Kemampuan Afektif Siswa dengan Gaya Belajar Auditori}

Berikut dipaparkan hasil angket siswa dengan gaya belajar auditori dari 3 sumber, yaitu 1 siswa dengan gaya belajar auditori, 1 guru IPA, dan 1 teman sebangku siswa dengan gaya belajar auditori: 


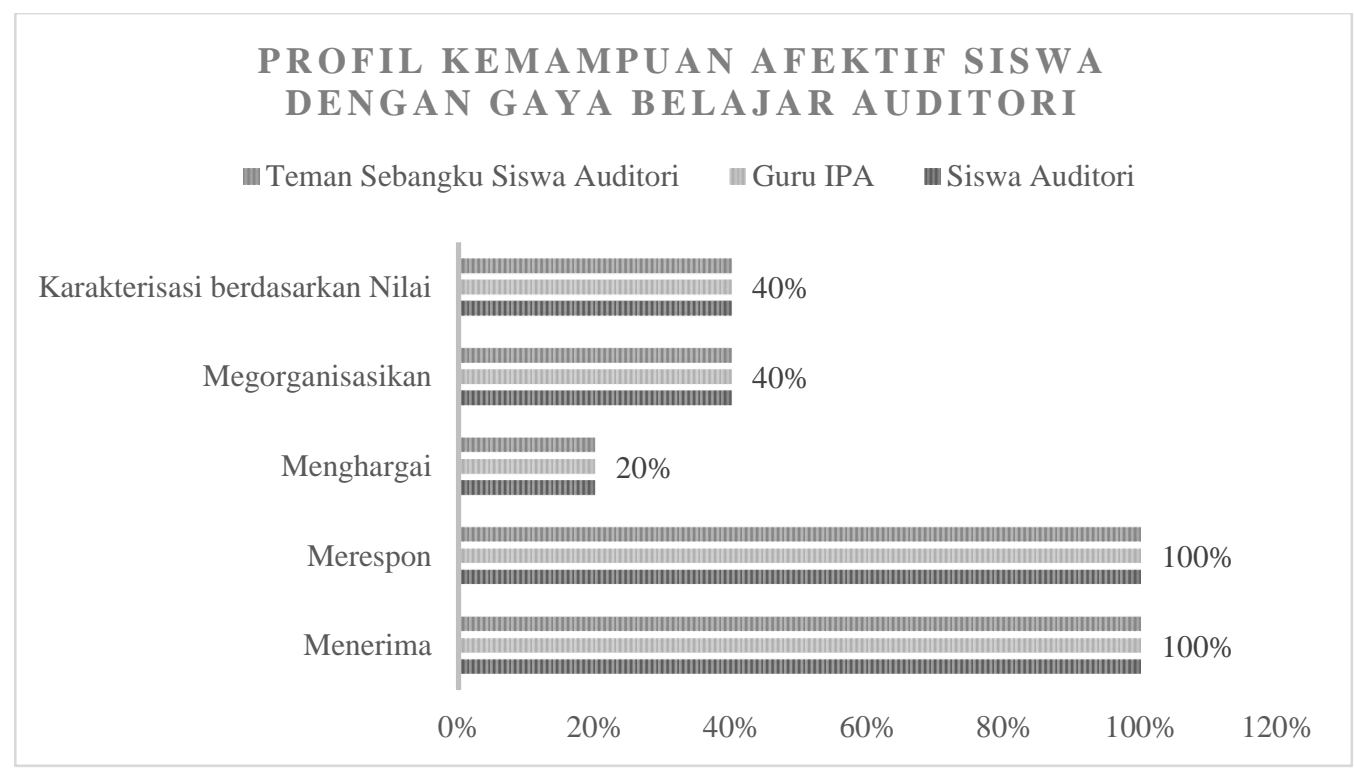

Gambar 2. Diagram Profil Kemampuan Afektif Siswa dengan Gaya Belajar Auditori

Profil kemampuan afektif siswa dengan gaya belajar auditori yaitu dari 5 indikator ada 2 indikator yang muncul semua yaitu indikator menerima dan merespon, sedangkan 3 indikator yang tidak muncul yaitu menghargai, mengorganisasi, dan karakterisasi berdasarkan nilai. Kemampuan afektif siswa auditori juga bergantung kepada karakteristik individu dan gaya belajar auditori itu sendiri. Seperti yang kita ketahui gaya belajar auditori adalah orang yang komunikatif, suka kerapian, ramah, biasa membaca dengan pelan dan bisa berdiam diri dengan waktu yang cukup lama (Sugiyono, 2011). Siswa dengan gaya belajar auditori hanya mampu memunculkan 2 indikator kemampuan afektif saja. Berdasarkan hasil informasi dari guru IPA, diperoleh bahwa kemampuan afektif siswa dengan gaya belajar auditori bagus dengan karakter subjek sendiri yang dikenal ramah juga komunikatif. Siswa ini tergolong siswa yang berani, setiap ada kesempatan bertanya maka siswa tidak ragu menanyakan apa yang ingin ditanyakan. Selain itu, siswa dengan gaya belajar auditori adalah anak yang cukup tangkas meski dia memerlukan bantuan untuk memahami hal-hal yang baru atau sulit dimengerti. Dengan demikian benar adanya jika siswa dengan gaya belajar auditori hanya mencapai indikator menerima dan merespon. Hal ini sesuai dengan hasil penelitian Kuslaila dan Kusumanintyas (2017), bahwa siswa dengan gaya belajar auditori lebih baik dari pada kinestetik.

\section{Profil Kemampuan Afektif Siswa dengan Gaya Belajar Kinestetik}

Berikut dipaparkan hasil angket siswa dengan gaya belajar kinestetik dari 3 sumber, yaitu 1 siswa dengan gaya belajar kinestetik, 1 guru IPA, dan 1 teman sebangku siswa dengan gaya belajar kinestetik: 


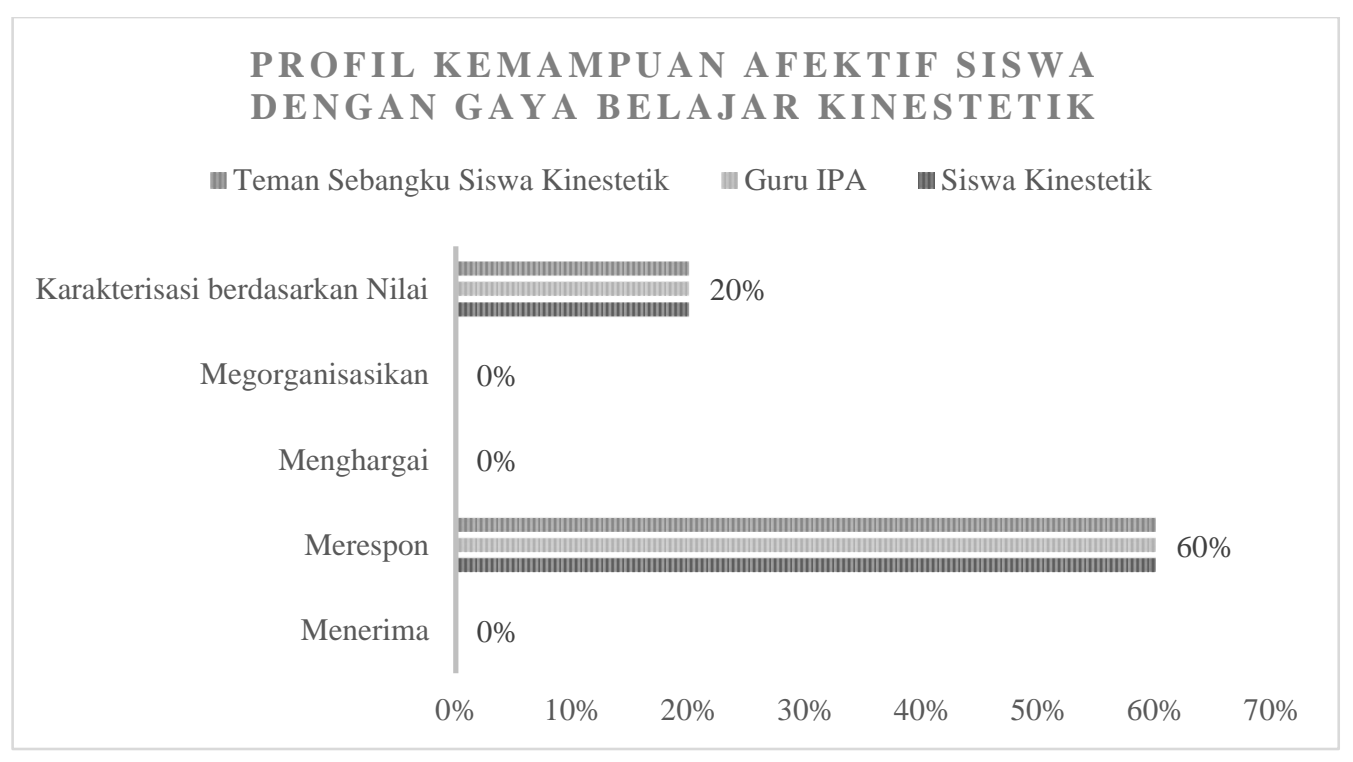

Gambar 3. Digram Profil Kemampuan Afektif Siswa dengan Gaya Belajar Kinestetik

Profil kemampuan afektif siswa dengan gaya belajar kinestetik yaitu dari 5 indikator tidak ada satupun indikator yang muncul seluruhnya, pada indikator menerima, menghargai, dan mengorganisasi tidak ada satupun aspek yang muncul, sedangkan pada indikator merespon hanya ada 2 aspek yang muncul dan pada indikator karakterisasi berdasarkan nilai hanya ada 1 aspek yang muncul. Dengan demikian dapat dikatakan bahwa kemampuan afektif siswa dengan gaya belajar kinestetik tidak muncul sama sekali. Informasi yang diperoleh dari guru IPA, bahwa faktor mata pelajaran favorit menjadi salah satu faktor nilai tidak baik pada subjek kinestetik. Mata pelajaran IPA bukanlah mata pelajaran yang subjek sukai (Rijal, 2015), tetapi guru mata pelajaran IPA adalah guru yang disukai. Siswa dengan gaya belajar kinestetik menjadi siswa yang tidak bisa memunculkan indikator kemampuan afektif. Siswa dengan gaya belajar kinestetik dikenal sebagai anak yang atraktif, beberapa waktu pernah tersangkut masalah di pondok pesantren sekolah. Siswa dengan gaya belajar kinetetik juga mengaku bahwa ia tidak begitu suka mata pelajaran IPA, kecuali gurunya. Siswa dengan gaya belajar kinestetik menganggap bahwa kemampuan afektif yang dia lakukan sudah baik, namun ini berbeda dengan pandangan dua (2) sumber yang lain yaitu guru IPA dan teman sebangku yang menilai kemampuan afektif siswa dengan gaya belajar kinestetik masih belum baik.

\section{SIMPULAN}

Berdasarkan hasil dan pembahasan yang telah dilakukan, dapat disimpulkan bahwa profil kemampuan afektif dalam pembelajaran IPA di SMP berbasis Pondok Pesantren di Sidoarjo Jawa Timur sebagai berikut: 1) siswa dengan gaya belajar visual telah mencapai semua indikator kemampuan afektif, yaitu menerima, merespon, menghargai, mengorganisasi, dan karakterisasi berdasarkan nilai, 2) siswa dengan gaya belajar auditori mencapai 2 indikator kemampuan afektif, yaitu menerima dan merespon, dan 3) siswa dengan gaya belajar kinestetik mencapai 1 indikator kemampuan afektif yaitu merespon. Penelitian selanjutnya diharapkan dapat mengembangkan kemampuan afektif siswa dari gaya belajar yang dimilikinya, khususnya dalam mata pelajaran IPA di SMP.

\section{REFERENSI}

Aliffah, N., Ashadi, A., \& Hastuti, B. Pengaruh Metode Pembelajaran Kooperatif Tipe Teams Games Tournament (Tgt) Dan Gaya Belajar Terhadap Prestasi Belajar Siswa Pada Materi Pokok 
Hidrolisis Garam Kelas XI Semester 2 SMA Negeri 4 Surakarta Tahun Pelajaran 2012/2013. Jurnal Pendidikan Kimia Universitas Sebelas Maret, 2(4), 80-89.

Amin, M. (2016). Pengaruh Mind Map dan Gaya Belajar terhadap Hasil Belajar Matematika Siswa. Tadris: Jurnal Keguruan Dan Ilmu Tarbiyah, 1(1), 85-92.

Anggito, A., \& Setiawan, J. (2018). Metodologi penelitian kualitatif. CV Jejak (Jejak Publisher).

Anggraini, K., \& Anatri Desstya, S. T. (2019). Pengaruh Gaya Belajar Dan Kedisiplinan Terhadap

Hasil Belajar Siswa Kelas V SD Negeri Kleco 2 Surakarta Tahun Pelajaran 2018/2019 (Doctoral dissertation, Universitas Muhammadiyah Surakarta).

Arini, Eviyanti Dian. (2017). Analisis Miskonsepsi Siswa SD Kelas VI pada Materi IPA Ditinjau Dari

Gaya Belajar. Sidoarjo: Skripsi PGSD Universitas Muhammadiyah Sidoarjo.

Basrowi, S. (2012). Evaluasi Belajar Berbasis Kinerja. Bandung: Karya Putra Darwati.

Bire, A. L., Geradus, U., \& Bire, J. (2014). Pengaruh gaya belajar visual, auditorial, dan kinestetik terhadap prestasi belajar siswa. Jurnal Kependidikan: Penelitian Inovasi Pembelajaran, 44(2).

Gunawan, I. (2013). Metode penelitian kualitatif. Jakarta: Bumi Aksara, 143.

Hartati, L. (2015). Pengaruh gaya belajar dan sikap siswa pada pelajaran matematika terhadap hasil belajar matematika. Formatif: Jurnal Ilmiah Pendidikan MIPA, 3(3).

Khoeron, I. R., Sumarna, N., \& Permana, T. (2014). Pengaruh Gaya Belajar terhadap Prestasi Belajar Peserta Didik pada Mata Pelajaran Produktif. Journal of Mechanical Engineering Education, 1(2), 291-297.

Kuslaila, M., Ningsih, E. F., \& Kusumaningtyas, W. (2017). Eksperimentasi Model Pembelajaran Pair Checks Pada Materi Pokok Segitiga Ditinjau Dari Gaya Belajar Peserta Didik. JIPMat, 2(2).

Hasibuan, A. P. (2018). Bimbingan Orang Tua Dalam Mencegah Anak Dari Penyalahgunaan Narkoba Di Jalan Juang 45 Desa Medan Estate Kecamatan Percut Sei Tuan (Doctoral dissertation, Universitas Islam Negeri Sumatea Utara Medan).

Mulyasa, E. (2014). Guru dalam implementasi kurikulum 2013. Bandung: PT Remaja Rosdakarya Offset.

Nyumirah, S. (2013). Peningkatan kemampuan interaksi sosial (kognitif, afektif dan perilaku) melalui penerapan terapi perilaku kognitif di rsj dr amino gondohutomo semarang. Jurnal keperawatan jiwa, 1(2).

Prastawa, F. R. (2013). Persepsi Guru Pendidikan Jasmani Sekolah Menengah Atas Negeri Se-Kota Yogyakarta Tentang Penilaian Domain Afektif. Jurnal Pendidikan Jasmani Indonesia, 9(2).

Rijal, S., \& Bachtiar, S. (2015). Hubungan antara sikap, kemandirian belajar, dan gaya belajar dengan hasil belajar kognitif siswa. Jurnal Bioedukatika, 3(2), 15-20.

Rosa, F. O. (2015). Analisis Kemampuan Siswa Kelas X pada Ranah Kognitif, Afektif dan Psikomotorik. Omega: Jurnal Fisika dan Pendidikan Fisika, 1(2), 24-28.

Salim, A. (2018). Pendidikan Karakter dan Eksistensi Pemuda. Potret Pemikiran, 19(2).

Sugiyono, P. (2011). Metodologi penelitian kuantitatif kualitatif dan R\&D. Alpabeta: Bandung.

Sukanti, S. (2011). Penilaian Afektif Dalam Pembelajaran Akuntansi. Jurnal Pendidikan Akuntansi Indonesia, 9(1).

Sulistyowati, F. S. (2014). Pengaruh lingkungan sekolah dan pengetahuan terhadap perilaku kekerasan di kalangan pelajar (Doctoral dissertation, UNS (Sebelas Maret University).

Taiyeb, A. M., \& Mukhlisa, N. (2015). Hubungan Gaya Belajar dan Motivasi Belajar dengan Hasil Belajar Biologi Siswa Kelas XI IPA SMA Negeri 1 Tanete Rilau. bionature, 16(1). 